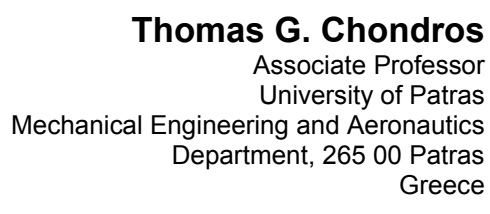

Thomas G. Chondros

Associate Professo ( Greece

\section{The Development of Mechanics and Engineering Design and Machine Theory since the Rennaissance}

The history of science and mechanics is confronted by two interconnected problems: a critical accumulation and systematization of historical information about the subject of study, and the relationship between events and the laws of their development.The influence of natural philosophy in classical times that led to the development of mechanics and engineering as a science from the $5^{\text {th }}$ century B.C. to the Middle-Ages was investigated in a previous article by the author. The rapid development of mechanics as a science started in the 16th and the 17th century. Machine design as an applied science was heavily relying on mechanics. Since the beginning of the 19th century, mechanics became the theoretical basis of an increasing number of applied technical disciplines directly connected with the development of industry, the elaboration of new technological processes machines, and industrial plants. A brief history of the development of the theory of machines and mechanisms is attempted here, along with the personalities and Academic Institutions that influenced Mechanisms amd Machine Theory from Medieval Times to the recent past.

Keywords:Natural Philosophy, Mechanics, Engineering, Design, Vibration.

\section{INTRODUCTION}

A.D. Dimarogonas (1938-2000) in his book Machine Design A Cad Approach(John Wiley and Sons 2001) provides a comprehensive historical introduction with important issues concerning the development and integration of natural philosophy, mechanics, engineering, and technology [1]. In the rhetorical question, What is Engineering? he refers to the famous jazz musician Louis Armstrong, once asked to define jazz. His answer was "If you got to ask, you'll never know". Aristotle's idea on engineering incorporating a sense of wonder is mentioned too:

Nature works against man's needs, because it always takes its own course. Thus, when it is necessary to do something that goes beyond Nature, the difficulties can be overcome with the Assistance of Engineering. Mechanics is the name of the engineering discipline that helps us over those difficulties; as the poet Antiphon put it, "engineering brings the victory that Nature impedes".

Kinematics and machine design have a distinct place in the history of engineering. The history of engineering science and mechanics is confronted by two interconnected problems: a critical accumulation and systematization of historical information about the subject of study, and the relationship between events and the laws of their development. The subject matter of mechanics is made up of motion and forces, specific phenomena of nature, thus making the history of mechanics part of the history of development of human society. Mechanics

Received: January 2021, Accepted: March 2021

Correspondence to: Thomas G. Chondros PhD,

University of Patras, School of Engineering, Mechanical

Engineering and Aeronautics Department, 26500

Patras, Greece. E-mail: chondros@upatras.gr

doi: $10.5937 /$ fme2102291C

(C) Faculty of Mechanical Engineering, Belgrade. All rights reserved grew out of knowledge accumulated in the making of tools of labour, buildings, and the first machines, regarded in antiquity as the science of machines, developed under the influence of practical demands of society, linked to production, technology, and the study of motion of celestial bodies, mainly for navigation [2-8].

Mechanics' roots lie deep in physics, and interacts with engineering and nature using mathematical methods.Attempts at understanding the fundamentals of mechanics go back to antiquity, but scientific conceptions concerning mechanical phenomena accumulated very slowly during the first stages of the history of human culture. Mathematics as a discipline was tightly coupled with technological achievements.There were three main institutions in the Ancient Greek World that contributed toScience and Technology: Plato's Academy, Aristotle's Lyceum, and The Library of Alexandria [9-11].

Basic scientific principles discussed and explained by Archimedes in the $3^{\text {rd }}$ century $\mathrm{BC}$ formed the instrument upon which engineering was established as a science distinct from crafts and unrelated empirical rules. Ctesibius, and his students Philo and Heron, and Pappus of Alexandria wholived in the second century B.C. through the first century A.D. have introduced analytical methods for the study and design of advanced machines and mechanisms, not always driven by practical needs. Their pioneering contributions influenced the western science and technology and their writings were reprinted until the $16^{\text {th }}$ century A.D.The Alexandrian school marksan important transition from very simple mechanisms to the more complex devices that could be considered machines. The School of Alexandria provides the starting point for modern mechanical practice and engineering design. The Antikythera mechanism, ca $2^{\text {nd }}$ century B.C. (Fig. 1), incorporates a wealth of information on the calculation and engi- 
neering capabilities of the ancient Hellenistic world. This era of rapid advances in engineering and mechanics could be connected to the expedition of Alexander the Great to the East [1-10].

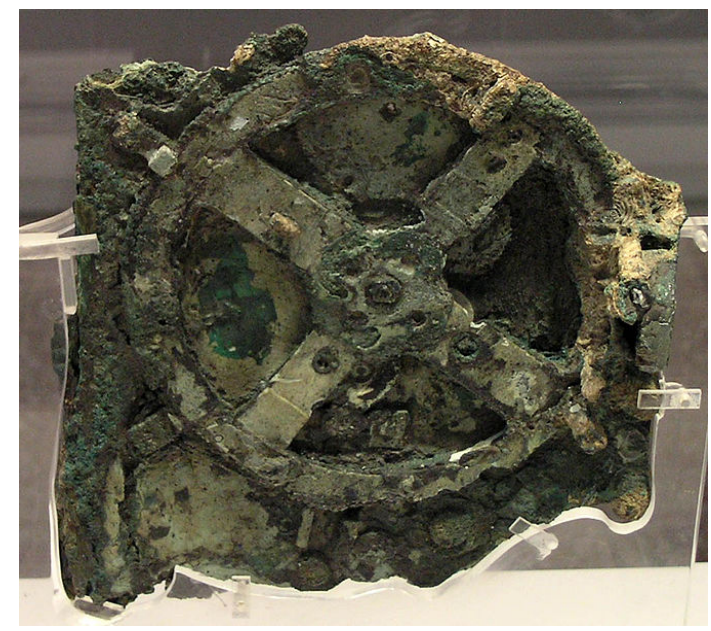

Figure 1.The Antikythera mechanism, (Courtesy of the National Archaeological Museum of Athens).

Artobolevski (1905-1977) in an effort to describe the development of the theory of machines and mechanisms mentions that it is important toestablish at least approximately the point of its origin asa science, considering that the science of machines after the Renaissance was for a long time of a purely empirical inventive nature without a theoretical substantiation of their design. The design of machines and mechanisms in a systematic way, using a mathematical axiomatic foundation and experiments, is a process not arrived at empirically through long evolution, and this point separates engineering science from technology and crafts. The development of mechanics was closely associated with the development of mathematical methods. The appearance and refinement of mathematical methods permitted the statement and solution of more complicated problems of mechanics. In turn, problems of mechanics stimulated the intensive development of mathematical methods. The history of mechanics and the design of tols, machines, and mechanisms is strictly connected with the development of human society [8].

In a previous article a study on the history of engineeringg and mechanics from antiquity up to medieval times was reported. This paper continues with the investigation of the work of individual scientists, mathematicians and engineers during the early-modern and modern times of mechanics and engineering, in conjunction with engineering education and Institutions and their contribution in society welfare [9].

\section{MEDIEVAL TIMES}

The tradition of scholarship kept knowledge alive from the ancient scientific texts via scholarly discussions and the publication of commentaries in addition to original texts. By the year 600 A.D. significant efforts to turn part of the Greek corpus of scientific learning into Latin in the West and into Syrian in the East took place. Greek science was converted first into the Arabic in the $9^{\text {th }}$ and $10^{\text {th }}$ centuries and then once again from Arabic and Greek into Latin in the $12^{\text {th }}$ and $13^{\text {th }}$ centuries. The diffusion of Roman culture into highly religious medieval Europe shifted the emphasis to the practical needs of worshipping God. The influence of the works of the pioneers of science and engineering in classical times in medieval and the early modern era was due mainly to Latin and Greek-Latin versions handwritten, and then printed from the thirteenth to the seventeenth centuries. Translations into modern European languages came later, and have contributed to an ongoing study in the fields of the History of Greek Mathematics, History and Philosophy of Science and Engineering [1-4].

Although the records of machines and mechanisms during the "Dark ages" between 500 and 1000 are rare, large-scale changes in agricultural methods yielding agricultural surplus, led to rapid urbanization with a parallel development of mechanical devices suited to production, and to exploit the "natural powers" of wind and water. These new powers were to spawn a multitude of machines with complex mechanisms [1-4].

In the $9^{\text {th }}-10^{\text {th }}$ centuries clocks with gear drives were already in operation. In medieval monasteries, important mechanical devices were conceived. Documents of twelfth and thirteenth centuries containing machine sketches are few and the designers' enterprise is limited by available materials and tools rather than by lack of imagination. Bacon in the $13^{\text {th }}$ century refers to the capability of assembling a variety of machines [12-14]. In the Renaissance, Alberti (1404-1472) describes a variety of mechanisms needed in the construction of buildings. This is anearly attempt for a machine to be represented as a collection of mechanisms [15].Areas in northern and western Europe, once sparsely populated, came under cultivation. Grain was an important crop, most of it was ground by water mills. Depletion of population from Black Death marks the end of this period.

In the first half of the second millennium $\mathrm{AD}$ there was substantial dissemination of Aristoteles works and a renewed interest in mechanics and kinematics, in particular. Jean Buridan (c. 1350) and Albert of Rickmersdorf (c. 1350), known also as Albert of Saxony, both rectors of the University of Paris at different times, were instrumental in reviving Aristoteles writings by publishing translations of his works, and writing commentaries on his theories [1-5].

Nicole Oresme (1330-1382), who was a Buridan disciple and grand master of the College of Navarre, was given by Charles $\mathrm{V}$ the task of translating into French some of the works of Aristoteles. Oresme wrote treatises of his-own on mechanics, introduced the Cartesian coordinate system and studied the uniformly accelerated motion introducing the accurate law of distance travelled, $\mathrm{s}=1 / 2 \mathrm{gt}^{2}$, in contemporary terminology. Moreover, he introduced the basic ideas of continuum mechanics, defining the continuously varying qualities [16].

In the 14th century the development of arts, science and technology is followed by the creation of more complicated machines and mechanisms. This era became the period known as Renaissance. Movable type printing was reinvented in Europe around 1440 from Gutenberg (1398-1468). Vitruvius' books became very popular and had an immense influence on architects and scholars throughout the later middle ages. A copy of Vitruvius' work, unfortunately without drawings, was 
discovered in the monastery library at Monte Casino in 1414 and in 1486 it was printed by the Gutenberg press as the seventh book following their edition of the Bible. Reprints continued up to 1575 and each contained not only Vitruvius' original Latin text and a translation, but comments, explanations and advice. This Latin treatise De Architectura is one of the works of its kind to survive from the Roman world, among others Publius Flavius Vegetius Renatus, the Anonymous author of $D e$ Rebus Belicis, Sextus Julius Frontinus, Pliny the Elder, Marcus Terentius Varro [16, 17].

The 15th century was primarily the time of the absorption of classical studies and the adoption of Arabic mathematics. Design methodology returned to the level of a craft, and no noticeable advancements were recorded until the time of Leonardo da Vinci (1452-1519). The two manuscripts of Leonardo da Vinci (the Madrid Codex I and the Madrid Codex II) show that he had not only come close to the concept of a mechanism, but even attempted to give a systematic description of mechanisms and their components. His mechanical principles were based on utilization of cantilevers, leverage, pulleys, gears and cranks (Fig. 2). A similar approach is described in Franz Reuleaux' (1829-1905) classical treatise The Kinematics of Machines in 1870 [18-20].

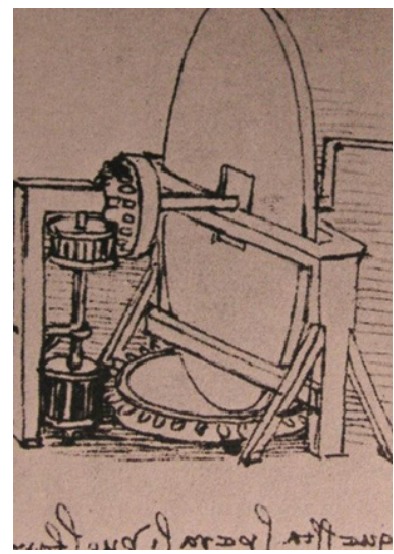

Figure 2. Leonardo's Lens Grinder [19].

Giovanni Fontana (ca. 1395 - ca. 1455) composed one of the earliest Renaissance technological treatises, Bellicorum instrumentorum liber.Hisworks include water-clocks, sand-clocks, measurement devices, and lifting and siege machines [21]. Figs 3-6 show some of the devices and mechanisms depicted in [22].

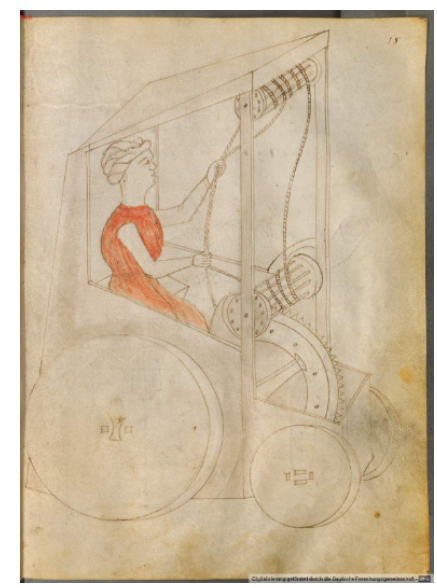

Figure 3. A self-propelled car [22].

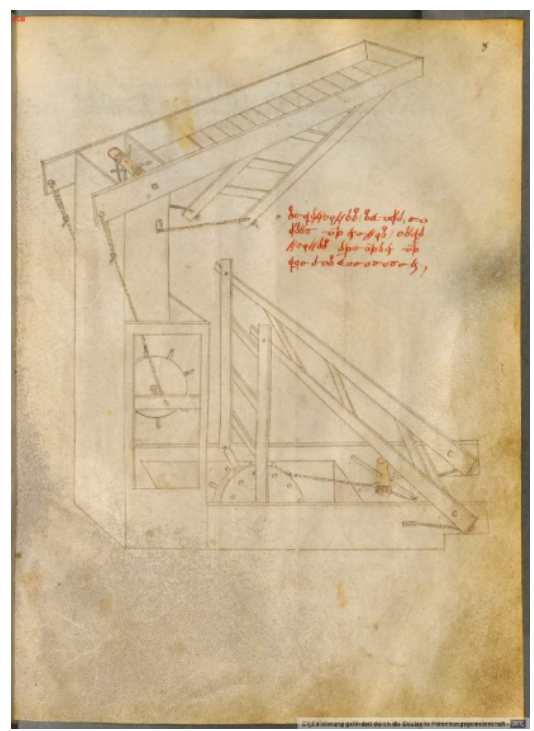

Figure 4.A siege machine with a linked boom [22].

The Renaissance saw a further extensive development of machine technology. In the works of L. B. Alberti (1404-1472) machines arerepresented as collections of separate mechanisms [15].

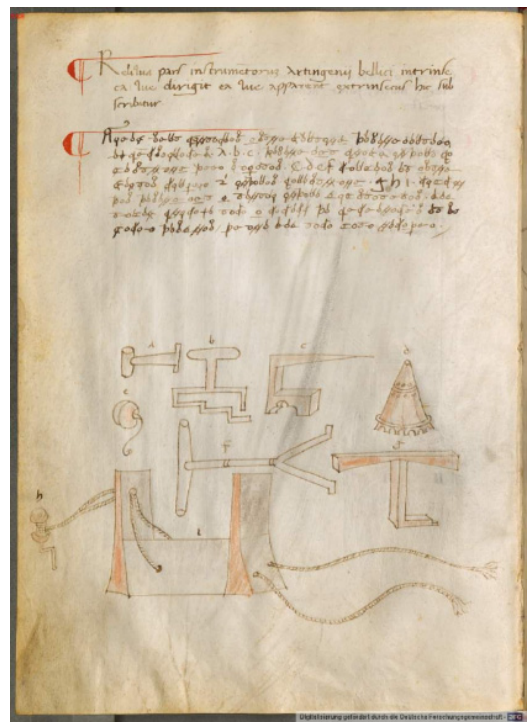

Figure 5.Parts of a lathe operated with a crank [22].

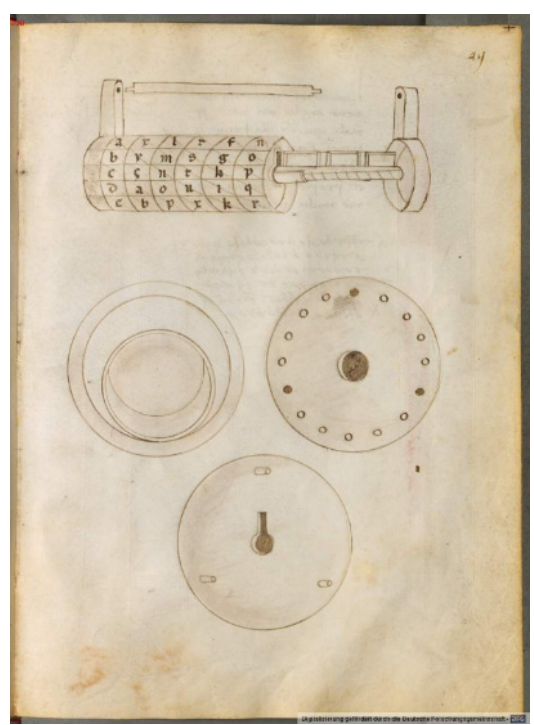

Figure 6. An automatic clock and calendar device [22]. 
Astronomer Nicolaus Copernicus (1473-1543) provided the first modern formulation of a heliocentric model of the solar system, a fundamental contribution to the mechanics of celestial bodies [23].

During the late Middle-Ages, the increasing demand for metals drove miners deeper into the earth. Miners started using water wheels to pump water from the mines, grind ore, run bellows at the blast furnace, and operate hammers at the metalsmith's forge, shown in Figs. 7 and 8 [24-25].

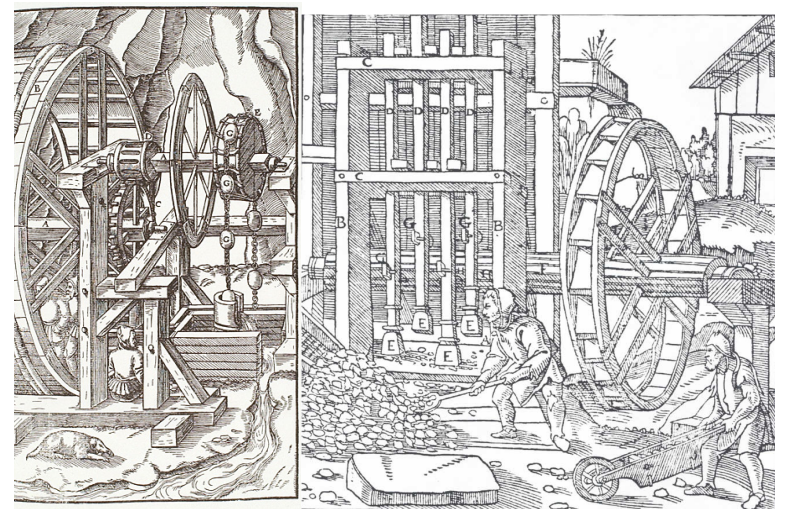

Figure 7.A mine pump (left) and the cam principle applied in a rock-crushing mill (right) as illustrated by Georgius Agricola's De Re Metallica (1556) [24-25].

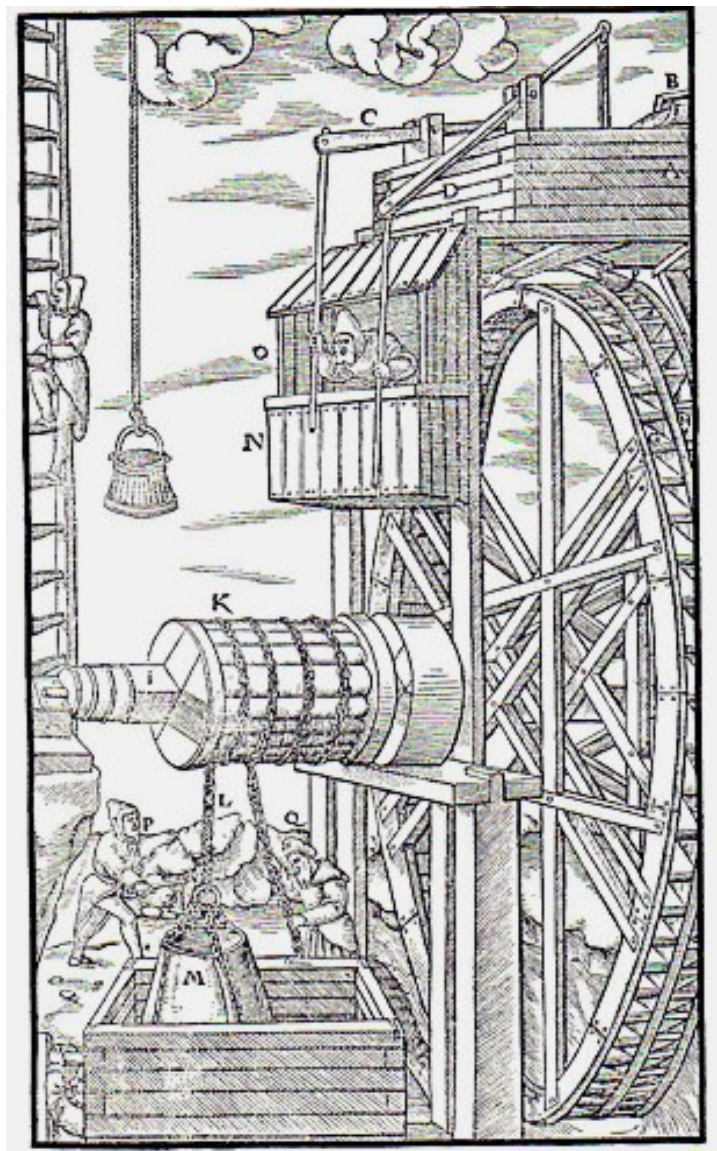

Figure 8.A mine water powered lifting machine in Georgius Agricola's De Re Metallica (1556) [4, 24-25]. Rotation is reversed by valves activated by the operator permitting water flow towards appropriate direction.

While De Re Metallica is of the most general interest of all of Georgius Agricola's (1494-1555) works [2-5], yet, from the point of view of pure science,
De Natura Fossilium and De Ortu et Causís are works which deserve an equally important place [25].

The period of the Renaissance is intimately linked with the name of Leonardo da Vinci, although his work was inspired by scholars and engineers of his time, Giovanni Fontana, with his marvellous automata, and other inventions of incredible modernity, Lorenzo Ghiberti, Mariano di Jacopo, Francesco di Giorgio Martini, among others [18-19].

Rapid development of mechanics as a science started in the 16 th and the $17^{\text {th }}$ century.Design methodology is at the craft level, recorded by several authors, and not noticeable advancements are reported until Leonardo da Vinci. Though there are no accounts for a specific design methodology, in his sketch papers one can see a systematic development of design concepts to arrive at specific solutions. This has little impact on his contemporaries because, among other reasons, his sketches were published centuries later. Leonardo's designs are characteristic of the sixteenth century where many pictorial books appear with a variety of drawings of machines, which was easier to draw and understand to craftsmen than text and mathematics. This indicates the level of machinery making as of a mere craft. The need for accurate time keeping in the monasteries brought about the need for a better time reckoning which led to the development of the pendulum clock, a remarkable mechanism which had a paramount effect in the development of the modern western science and civilization starting with Galileo Galilei (1564-1642) [26].

Galileo was educated in Greek, Latin and Logic, studied the works of Euclides and Archimedes and became familiar with the work of Leonardo da Vinci in mechanics. He conducted his famous experiments with falling bodies which were published in 1590 in the treatise De Motu Gravium. Galileo's discussions on the isochronism of the pendulum stirred a new interest in kinematics and mechanisms. His death interrupted his work on the development of a pendulum clock and his son continued this work.

While the originality of Galileo's ideas is a controversial matter, his works and life contributed substantially to the movement which brought together many men with scientific interests in experimental work. A culmination of this movement was the establishment in Naples of the Academia Saccretorum Naturae in 1560 and the Academia dei Lincei in Rome in 1606, and Galileo was one of its members. After Galileo's death in 1642, the Academia del Cimento was organized in Florence and in 1662 the Royal Society in London. In 1666, the French Academy of Science and in 1770 the Berlin Academy of Science were organized. All these academies published their transactions and these had a great influence on further development of science in the eighteenth and nineteenth centuries.

\section{EARLY MODERN AND MODERN ERA HISTORY OF MECHANICS}

The subjects of Mechanical Engineering have attracted more and more interest since early Renaissance both for practical applications and from a theoretical viewpoint in response to an increase of societal needs. Several 
studies and designs of machinery were developed during Renaissance, but the matter did not get the dignity of a discipline, although it achieved significant advances. Alberti's treatises on painting and architecture exerted a great influence on $16^{\text {th }}$-and $17^{\text {th }}$-century artistic thought. The teachings of the French $17^{\text {th }}$-century academies of painting and architecture represent a first codification ofartistic principles $[8,12]$.

Rapid development of mechanics as a science began with the start of the $17^{\text {th }}$ century. The development of manufactories $\left(16^{\text {th }}-17^{\text {th }}\right.$ centuries $)$, the industrial revolution of the $18^{\text {th }}$ and the $19^{\text {th }}$ centuries, marked the development of mechanics [2-5,12].

Since the beginning of the 19th century, mechanics became the theoretical basis of an increasing number of applied technical disciplines directly connected with the development of industry, the elaboration of new technological processes machines, and industrial plants.New machines opened up wole eras in the development of technology and design. The Watt's steam engine,and the $18^{\text {th }}$ century developments associated with new designs of textile machinery, the flying shuttle invented by John Kay (1704-1779), R. Arkwright's (1732-1792)spinning machine, E. Cartwright's (1743-1823)mechanical machinetools, and his first power loom, and other pioneers $[8,12]$.

In the latter half of the $19^{\text {th }}$ century, mechanics attracted the attention of naturalists. The discovery of the law of conservation of energy and attempts to elaborate a unified mechanistic description of the cosmos, required understanding of the basic concepts of mechanics [10]. An important publication appears in the beginning of the $19^{\text {th }}$ century in Germany and France, The Encyclopädie der mathematischen Wissenschaften mit Einschluss ihrer Suwendungen. Articles were written by prominent scientists (P. Appel, G. Darwin, Th. Von Kármán, A.N. Krulov, H. Lamb, A.E.H. Love, R. von Mises etc) representing today valuable historic material [1-4].

Difficulties of a formal axiomatization of the concepts of mass and force brought forth a sharp discussion in the scientific circles. Reassessing Newton's laws of mechanics acquired great interest at those times. The Philosophy Department of Göttingen University awarded a contest in 1869 for the composition of a critical historic study on the basic principles of mechanics. The statement of the requirements pertaining to this investigation was posed as: "when and by whom and in what connection with specific problems was each separate essential principle of mechanics first found and enunciated", and results were expected in accordance with an analysis of the principles and their interrelationship with philosophical theories. A total of five compositions were submitted, first prize went to E. Dühring for his paper entitled Kritische Geshichte der allgemeinen Principiender Mechanik ( $1^{\text {st }}$ edition 1873). Next work by E. Mach Die Mechanik in iher Entwiklung Historisch-Kritisch Dargestellt. The philosophical issues arising from the works of Dühring and Mach caused criticism from Friedrich Engels (1820-1895) (Anti-Dühring, 1878) [27] and V. I. Lenin (Materialism and Empiriocriticism, 1909) [28] from the stand of dialectical materialism, and an interesting debate took place.
At the end of the $19^{\text {th }}$ century, the work of K. Pearson (1857-1936), History of the Theory of Elasticity and of the Strength of Materials from Galilei to Lord Kelvin (1886-1893) based on a manuscript of I. Todhunter remains an excellent review work on history of mechanics covering topics for over two centuries [29-302].

Over the $19^{\text {th }}$ century science has grown into a direct productive force, although sociological research that flourished during the first decades of the $20^{\text {th }}$ century perceived a direct relationship between each separate fact in the history of mechanics, and some factor in the development of the mode of production, or even of technology [7-12, 24].

At the start of the $20^{\text {th }}$ century P. Duhem (18611916) a French physicist, historian, and philosopher of science, investigated the mechanics of the Middle Ages providing the first analysis of medieval views on statics and dynamics. It must be mentioned here, that most of the nineteenth century, scholars treated "medieval science" as an oxymoron. Since nothing from the Middle Ages was worthy of the name "science," no history of medieval science could be written. In 1904, while writing Les origines de la statique, [31], Duhem came across an unusual reference to a then-unknown medieval thinker, Jordanus de Nemore. Duhem's research to de Nemore works led him in creating the field of medieval science history. Although he covered seventeenth-century statics in Les origines de la statique, he also returned to the middle ages, spending four chapters on geostatics, including the work of Albert of Saxony in the fourteenth century.

In 1916, Duhem wrote Le Système du monde, without finishing it. He intended it as a complete work on the history of cosmological doctrines, ending with Copernicus. He completed nine volumes, the first five being published from 1914 to 1919 , and the next four having to wait until the 1950s; a tenth, incomplete volume was also published then. In Duhemworks Etudes sur Léonard de Vinci, and Le Système du monde, his thesis of the continuity of late medieval and early modern science is clearly portrayed [32-35]. A number of surveys on medieval mechanics was later undertaken by A. Maier, A. Koyrè, E.A. Moody and M. Clagett [21].

Inthe 1950s, the worksby R. DugasHistoire de la Mecanique[36] and La Mecanique au 17e siècle [37] provide a comprehensive view of the development of mechanics. At the same time C. Truesdell started publishing his studies on the history of the general principles and methods of the mechanics of the continua in the $18^{\text {th }}$ and the beginning of the $19^{\text {th }}$ century. Some of his articles have been published in Essays in the History of Mechanics in 1968 [38,39]. Truesdell's works are distinguished by a profound use of source material, and original style of exposition. The historical essay of Th. Von Karman (1881-1963) a collection of six lectures he presented at Cornell University in 1953, is still the best introduction to the history of aerodynamics [40-43]. S.P. Timoshenko's historical review on Strength of Materials with a Brief Account of the History of Theory of Elasticity and Theory of Structures explores the early roots of the discipline from the great monuments and 
pyramids of ancient Egypt to the temples and fortifications of the Greeks and Romans [44].

Careful study of the works presented before, provides a clear insight on the emergence of mechanics in the $17^{\text {th }}$ century and subsequent development of discrete systems, in particular the variational principles. History of continuum mechanics starting in the $19^{\text {th }}$ and the $20^{\text {th }}$ centuries is under the focus of researchers, as well as the principle of relativity, automatic control theory, hydrostatics, hydrodynamic theory of lubrication, turbulence, the theory of plasticity and fracture mechanics.

\section{MECHANICS AND ACADEMIC EDUCATION}

By the middle of the $18^{\text {th }}$ century, technical schools began to play important role in engineering science development. The National school of bridges and roads opened to Paris in 1717. In 1745 a mining school in Brunswick. Among the graduates of the school of the Royal Engineering corps in Mesire were Carnot, Coulomb, Poncelet and Monge. A great impetus to the development of mechanics was given at the beginning of the $20^{\text {th }}$ century by problems arising in railway transport,and the associated construction of bridges, rapidly advancing shipbuilding, internal combustion engines, automobiles and particularly aviation [45]. During almost the whole $19^{\text {th }}$ century, the traditional content ofmechanics advanced mainly intheframework of so-called "applied mathematics".Toa certain extent, this was due tothe influence of Lagrange who regardedas the highest attainment the fact that, thanks to his work, mechanics is becoming a new branch of analysis" [10]. The early modern era is highlighted by the works of Galileo (1564-1642) and Newton (16421727) and includes the early stages of mechanization and the Industrial Revolution. At the universities no entities were devoted to the practical aspects of engineering. The subjects of mechanics were taught as an application of mathematics [7-12].

The study of motion of rigid bodies was recognized of fundamental importance since the beginning of a mechanical Science. Nevertheless, mathematical approaches have been formulated only from $17^{\text {th }}$ century, with the evolution of proper mathematical tools. The emergence of mechanics of the $17^{\text {th }}$ century was followed by the development of the basic principles of the mechanics of discrete systems, in particular the variational principles. In addition, technological requirements for mechanical devices did not require the study of threedimension motion until astronomical observations stressed no coplanar motion of the planets. Moreover, the Galilean approach gave the first formulation that was successfully used for machines design and operation for long time without any further improvements [46].

The first successful independent academic course on Mechanics of Machinery was given by Galileo Galilei (1564-1642) at the University of Padua in 1597-1598. He used the short treatise Le Mecaniche posssibly written in 1593. The treatise Le Mecaniche can be considered as a first academic textbook on the Theory of Machines and Mechanisms, that was used in the years 1593-1604 [26]. Le Mecaniche is considered as a minor work of Galilei's since it is regarded as a preliminary step in the development of the masterpieces of Galilei in the field of experimental mechanics. In Le Mecaniche, Galilei approaches the analysis of fundamental machines for lifting weights, namely lever ('lieva'), capstan ('argano'), pulleys ('taglie'), and screw ('vite'). A rigorous analysis of these machines is performed by Galilei by examining the physical phenomena of the machinery's operation and by using suitable models derived from early forms of descriptive geometry and kinematics. In addition, practical concerns are mentioned throughout the treatise so that it can be considered to also have been useful for practical engineering and design purposes $[26,46]$.

Newton (1643-1727) was the first starting from dynamics to deduce the theory of staticsin the introduction to the Principia published in 1687. Newton assumed that all geometrical magnitudes might be conceived as generated by continuous motion. This seems to be the earliest definite recognition of the idea of a continuous function [47]. The contemporary development of calculus and continuum mechanics led to the rapid development of mechanics by the mid $19^{\text {th }}$ century.

J. Leupold (1674-1727) an engineer, researcher and director of mining operations in Saxony from 1724 onward he wrote 11 books, covering all the different technical branches of science, including the Theatrum Machinarium a nine-volume series on machine design and technology published between 1724 and 1739. The eighth volume of Leupold's Theatrum Machinarum, (the posthumous ninth volume) was entitled Theatri machinarum supplementum. Like Leonardo, he separated out the individual mechanisms, gave detailed descriptions of gears and even wrote about the elements of gear reducers. Leupold in the early eighteenth century is the first to reference the idea of modifying a continuous circular motion into a back and forward motion, providing the first attempt at a systematic treatment of mechanisms. His nine-volume books published during the period 1724-1739 constituted a "display of the mechanical sciences" containing almost 500 engravings with details of machines for various practical applications [48].

The works of the mathematician and mechanician L. Euler (1707-1783). Euler published during 1736-1742, and the book Mechanica sine motus scientia analytice expositacontributed to the emergence of the science of machines. According to Lagrange it is "the first great work in which analysis is applied to the science of motion". Euler was the first to note that machines and mechanisms should be considered not in a state of rest but in motion, regard the kinematics of mechanisms as a separate science. Euler also wrote on the theory of friction, gear wheels, flexible link (belt, chain, rope) and gearing. In Mechanica appeared the concept that planar motion can be described by the translation of a point and a rotation around that point. This issue was further extended to velocity and acceleration and although the relevant equations came after Euler are given the generic title of Euler theorems [1-5, 49]. The formulae which give the variations of the coordinates of the points of a movable solid in space were published by Euler in 1750. D'Alembert (1717-1783) suggested the 
importance of studying the laws of movements separately. Ampère (1775-1836) drew a definite demarcation between mechanics and the geometry of movement, but his object was to develop kinematical science solely for its use in the theory of mechanisms; the term kinematics is due to Ampère [1-7].

Watt (1736-1819) in contrast with Euler concentrated on motion synthesis. Watt considered the motion of a point on the intermediate link of a four-bar mechanism thus, allowing him to build in 1784 a doubleacting steam engine. He explored the coupler-point motion of the four bar linkage, and applied this new range of motion in his double acting steam engine. The earlier chain connecting piston and beam was introduced in the Newcomen-type atmospheric engine circa 1775 , was now replaced by a linkage able to transmit force in two directions instead of one.Watt considered his rectilinear motion mechanism his top achievement. Several mechanisms to approximate linear motion were invented later by Cartwright, White, Evans, S. Roberts, and others. Watt had discovered the coupler-point motion a pivotal point along the road of synthesis [1-12].

D'Alembert individuated rigorously the instantaneous axis of rotation in 1749; Paolo Frisi (1728-1784) proved the theorem of composition of instantaneous rotations in 1759; Euler formulated the motion of rotation in a modern form in 1765; Lagrange (1736-1883), treated the motion of rotation with mathematical formulation in along with a detailed survey of the development of the principles of mechanics that can be found in Lagrange's Mechanique Analytique (1788). These works gave great impulse on the study of general motion of rigid bodies that brought to the fundamental work by Mozzi in 1763 and later the well known contributions on the Screw Theory that has been finally established by Ball in a modern treatment in 1876 [48-52].

The Newton-Euler equations describe in a precise way the complex rotary and translating motion of a rigid body. The Newton-Euler equations compose two Euler's laws for the solid-body motion (1760) in the form of matrices and vectors associating the motion of the body centroid with the sum of the forces and moments acting, paving the way for the theory of screws describing the dynamics of body systems connected to each other by links and joints of various types [1-12].

The general form of theNewton-Euler's Equations describe Euler's first and second law as:

$$
\sum \mathbf{F}_{i}=\frac{d}{d t} m \mathbf{v}_{c}
$$

where, $d m \mathbf{v}_{c} / d t$ time differential of the linear momentum equal to the sum of the external forces and moments applied, and

$$
\sum \mathbf{M}_{c i}=\frac{d}{d t}\left(I_{n} \boldsymbol{\omega}\right)=\frac{d}{d t}\left(\mathbf{H}_{c}\right)
$$

where, $d \mathbf{H}_{\mathrm{c}} / d t$ time differential of the angular momentum equal to the sum of the external moment applied, $\mathbf{H}_{\mathrm{c}}=\mathbf{I}_{1} \omega_{1} \mathbf{e}_{1}+\mathbf{I}_{2} \omega_{2} \mathbf{e}_{2}+\mathbf{I}_{3} \omega_{3} \mathbf{e}_{3}$ angular momnentum, $\mathbf{I}_{\mathrm{n}}$ the inertia Tensor, $\omega_{\mathrm{n}}$ the angular velocity vector component, $n=1,2,3$ the directions of the global coordinate system.
Later, in 1873 M. J. Bertrand based on Newton's formulations provided the subsequent formulations of the more general problems concerning the determination of the forces in acordance with the given properties of motion. Mathematically, the solution of Bertrand's problem consists of a system of two second order equations

$$
\begin{aligned}
& \ddot{x}=X(x, y) \\
& \ddot{y}=Y(x, y)
\end{aligned}
$$

For which a conic section is the integral curve.

The equation of the conic section is described by the equation

$$
\sqrt{x^{2}+y^{2}}=e x+p
$$

where $e$ is the eccentricity of the conic section, and pis half of the latus rectum. The origin of the coordinates system coincides with one of the foci, and the $x$-axis with the symmetry axis of the conic section.

Then, the solution of the system of Equations (3) and (4), under the appropriate assumptions provides the required force $F(x, y)$ under which a particle moves along a conic section under any initial conditions in the form

$$
X=c x, Y=c y
$$

where $\mathrm{c}=$ constant

Equations (5) imply that the required force is central and is directly proportoional to the distance between the moving particle and the centre of the conic section. The solution of the Bertrand's problem intrigued the solution of a series of problems of dynamics considering the problem of finding a force function $U$ determining the forces causing the motion of a holonomic mechanical system with given integrals, leading to the solution of general inverse problems of dynamics, under the assumption that he force field is a potential field. The solutions were further extended to the motion of particles with varying mass. Apart from astronomy, the space engineering was further enriched with the appropriate tools to proceed. Then, it was kinematics and dynamics of machines and mechanisms that were further benefited from the progress in inverse dynamics theories.

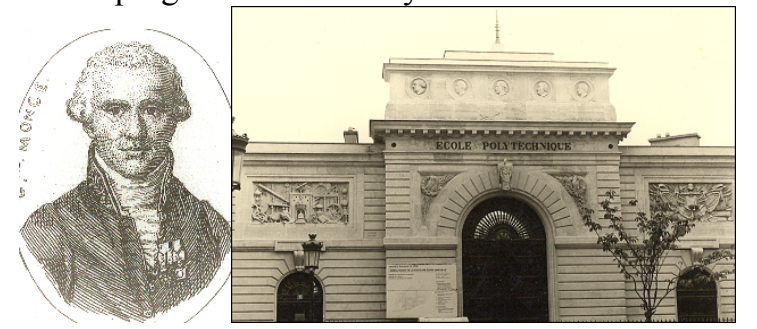

Figure 9. Gaspard Monge (1746-1818) Creator of the École Polytechnique, and the main building of the École Polytechnique in Paris (established in 1794).

Design of machines and mechanisms in modern times were established in 1794 when The Ecole Polytechnique in Paris, the first polytechnic school in Europe, established the separate study of kinematics from the study of machinery [66]. Gaspard Monge (1746-1818) one of the founders of the Ecole Polytechnique, the inventor of descriptive geometry had proposed a course on elements of machines for the Ecole Polytechnique. Monge included mathematician Lang- 
range (1736-1813) and Fourier (1768-1830) among his teachers.Fourier(1768-1830) and Poisson (1781-1840) soon joined them.Josè Maria de Lanz (1764-1839) and Agustin de Bètancourt Y Molina(1758-1824) [67] published in Paris, in 1808 the book Essai sur la composition des machines [7-12,53-55].

Jean Nicolas Pierre Hachette (1769-1834), a colleague of Monge and Carnot (1796-1832) the father of thermodynamics, in his book Traité élementaire des machines (1811) proposed the classification of the machine elements into six orders: recepteurs, receiving the motion from prime movers; communicateurs, passing on the motion; modificateurs, changing the type of the motion; supports; regulateurs, transmission ratio regulators; and operateurs, performing the machine function [54-55].

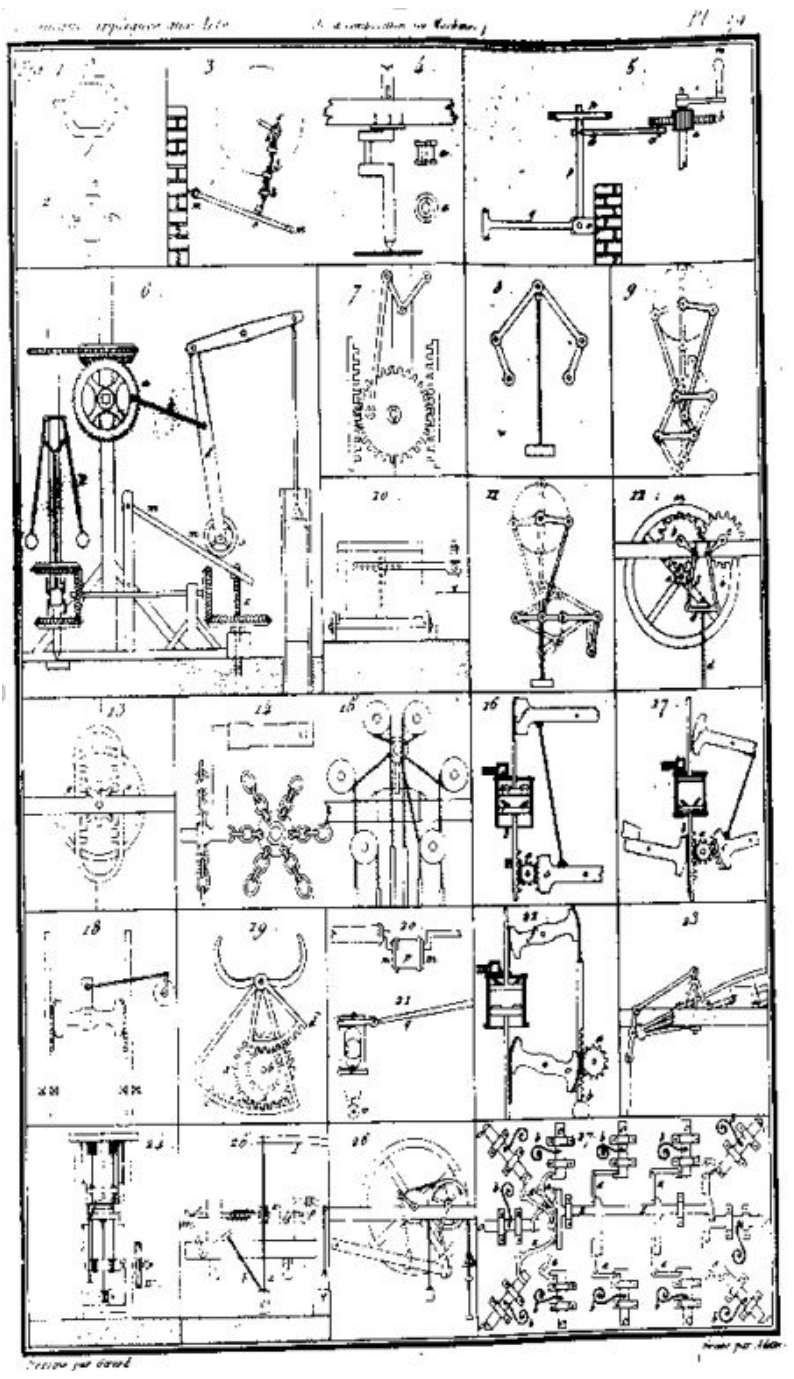

Figure 10. Part of a table of the classification of mechanisms by Gian Antonio Borgnis [71].

In 1830 Ampere published his Essai sur la philosophie des sciences defining the machine "...an instrument by the help of which the direction and velocity of a given motion can be altered". He excluded forces from kinematic analysis and gave to the study of such machine the name Kinematics from the Greek word KINHMA $=$ motion and the Science of Kinematics was born. In the new science "The movements are to be studied as movements, independent of the power creating them, in the same way as we observe the static bodies around us, especially in such combinations as we call machines... This science (Kinematics) ought to include all that can be said with respect to motion in its different kinds, independently of the forces by which it is produced" [1-8,12].

De Coriolis (1792-1843), road and highways engineer and professor in Paris, simplified Borgnis, Italian engineer and professor at the University of Padua, classification system, by reducing the concept of a complete machine to three groups; recepteurs, communicateurs and operateurs [56-58]. Fig. 10 shows part of a table of the classification of mechanisms by Borgnis [58].

In 1831, Coriolis was investigating relative motions and posed the fundamental problem of kinematic analysis: "to find the motion of any machine in which certain parts are moved in a given way" and introduced the ideas of relative velocity (known already to Aristoteles) and relative acceleration.In the works of Betancourt, Lanz and Hachette paid attention on mechanisms systematization [54-56].

The development of mechanisms facilitated engineer George Stephenson $(1781$ - 1848) to build the world's first public railways: the Stockton and Darlington railway in 1825 and the Liverpool-Manchester railway in 1830 . Meanwhile, he had built sixteen different steam engines, the most famous being "The Rocket" (Fig. 11) [4].

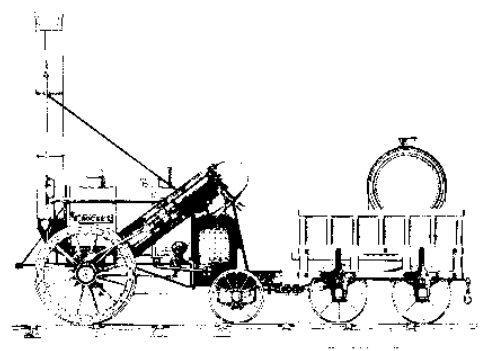

Figure 11. GeorgeStephenson's "Rocket", 1829, the first practical locomotive [4].

A considerable contribution to the theory of coupler curves in the course of the $18^{\text {th }}$ and $19^{\text {th }}$ centuries was made by F. Savary, M. Challis and T. Olivier the creators of kinematics geometry and the generalized theory of gearing [1-12]. Savary somewhere in the decade 1831-1841, derived the equation for the path curvature, the curvature of the paths traced on the fixed plane by points of the moving plane, and the envelope curvature, or curvature of the of the envelopes on the fixed plane of curves in the moving plane [1]. The idea of modelling tooth surfaces with conjugate surfaces was introduced by Olivier in 1842[57-58].

A comprehensive study of significant Italian kinematicians in the $18^{\text {th }}$ and $19^{\text {th }}$ century: Carlo Ignazio Giulio, Paolo Frisi (1728-1784), Gian Antonio Borgnis (1781-1863) Gaetano Giorgini (1795-1874), Ernesto Cavalli, Professor of kinematics in Milan in 1880-1908, Domenico Tessari (1886-1925), Lorenzo Allievi (18561941), and Francesco Masi (1852-1944), can be found in the works of Ceccarelli [59-60].

In the first half of the 19th century, a number of scientists effectively developed problems in the dynamics of machines. Thus, S.D. Poisson (1781-1840) examined the question of setting up the equations of motion 
of machines in the most general form. His book Traité de Mecanique was first published in 1811 [61]. De Coriolis also examined the problems of the dynamics of machines in the most general form with account of the forces acting on it [56].

The works of J. V. Poncelet (1788-1867) constituted a whole epoch in the science of machines, in particular, his fundamental treatise $A$ Course of Mechanics in Its Application to Machines. He derived the kinetic-energy equations for machines, considered the question of ensuring nonuniform operation of machines and the theory of a centrifugal governor. In later works, Poncelet considered the dynamics of machines with account taken of moving forces, forces of resistance, inertia and weight. $\mathrm{He}$ is also credited with the theory of transfer mechanisms, such as gears, friction mechanisms, cam mechanisms and others. In 1838 Poncelet included the geometric properties of moving bodies in his course at the Faculty of Sciences of Paris. Poncelet was director of the Ecole Polytechnique from 1848 to 1850 [1-12,62-63].

In the mid-19th century, a considerable contribution to the science of mechanisms was made by the English scientist R. Willis (1800-1875), a professor of natural and experimental philosophy teaching kinematics at Cambridge, and his lectures were published in the book Principles of Mechanisms. His work was devoted to the theory of mechanismswhich dealt with applied kinematics in the Ampere's sense and classified mechanisms on the basis of the change in directional relation and velocity ratio, and identified different ways in achieving each function. He set up a classification of mechanisms, the fundamentals of which are still of value today. The fundamental unit of his classification was the ratio of the speeds between the input and output links. This is followed by a separation of classes into groups depending on the type of the motion transmitted. To him also is credited the famous "Willis theorem" for gear drives [1-12,64].

Among those who took up Willis ideas was Ferdinand Redtenbacher (1809-1863), professor at Karlsruhe Technical University, a great teacher who played an important role in the dissemination of Willis ideas. Moreover, he inspired one of his students, Franz Reuleaux (1829-1905), to become fascinated with kinematics. Reuleaux was born to a family of master builders and his father was designer and builder of steam engines. He studied engineering in Karlsruhe, natural sciences in Berlin and arts in Bonn. He taught a few years at the ETH in Zurich and moved to Berlin Technical University where he compiled a "mechanical alphabet" of mechanical devices of his-own. The advancing mechanization has created a great number of different machines and mechanisms and Reuleaux embarked in an attempt to systematize and classify them.

Known already from his 1854 book Machine Elements and the 1861 handbook The Designer, Reuleaux published in 1875 the Theoretische Kinematik which was translated immediately in English (1874-1876) by Kennedy under the title Kinematics of Machinery, where a complete treatment of kinematics of mechanism is presented. He defines the machine as "a combination of solid bodies, so arranged as to compel the mechanical forces of nature to perform work as a result of certain determinative movements".A great number of different machines and mechanisms are classified in a "mechanical alphabet". The six basic mechanical components introduced by Releaux are: (1) the eye-bar link called crank in kinematics; (2) the wheel and gears; (3) the cam; (4) the screw for force and motion transfer; (5) the intermittent motion devices; and (6) the belts, chains and hydraulic lines. Each of these components was invented in antiquity and put in use fairly well in war machinery since the third century $B C$ Moreover, he deals with very important aspects of kinematics, such as pairing and inversion of mechanisms [1].

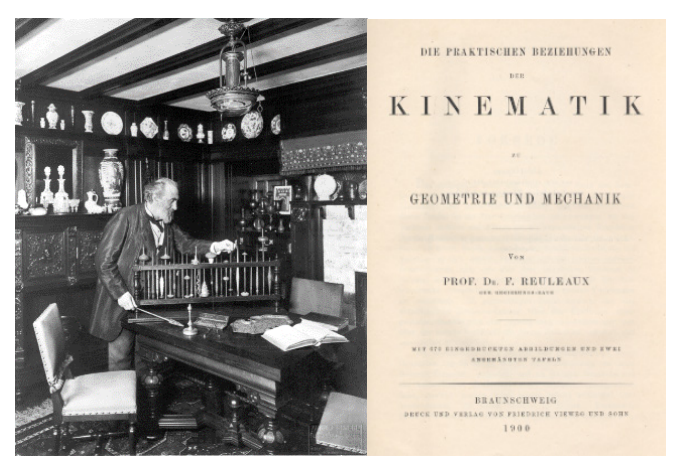

Figure 12. Franz Reuleaux (1829-1905) with his SpindleCollection and his main work Kinematic (1875-1900) [1].

In the same period, the German scientist Julius Weisbach (1806-1871) published in 1865 the threevolume work Ingenieur- und Maschinenmechanik devoted to the engineering principles of designing machines and certain problems of kinematics and dynamics of mechanisms. W.K. Clifford (1845-1879) developed the Clifford geometric algebras utilised in engineering mechanics (robotics) and the dynamics within systems of particles and rigid bodies [65].

John Macquorn Rankine (1820-1872) has devoted a good part of his book Machinery and Millworks (1869) to machine kinematics. Rankine considers a machine to be made up of a frame and moving pieces. The frame is the fixed link, in the language of Reuleaux and further Rankine makes an extensive use of the instantaneous centers of rotation. Although he introduces the elementary combinations of elements, he lacks the generality of Reuleaux treatment but he presents more specific results for particular forms of mechanisms [65].

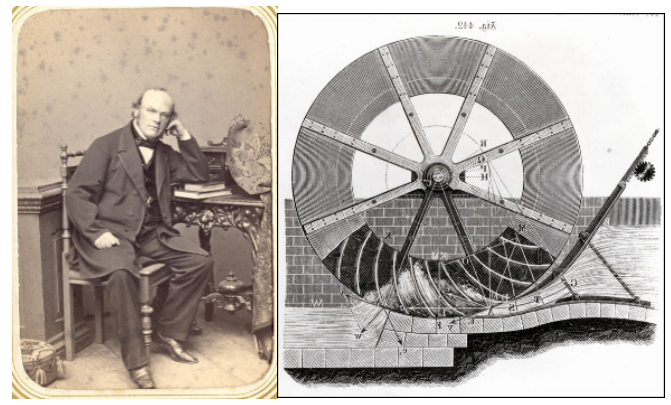

Figure 13.Julius Ludwig Weisbach (1806-1871) and his Description of the Poncelet's Water-Wheel in his Book Ingenieur- und Maschinenmechanik (1865) [65].

A Russian school in the theory of mechanisms emerged in the middle of the $19^{\text {th }}$ century and is 
associated with the name of P. L. Chebyshev (18211894), the founder of the theory of the structural and kinematic synthesis of mechanisms. He realized more fundamentally than any of his predecessors the role played by mathematics in solving problems of the synthesis of mechanisms. His writings became the foundation on which there grew up analytical methods of the synthesis of mechanisms that have come to fruition in our day [1]. Alexander Yershof's (1818-1867) book Foundation of Kinematics or Elementary Theory about Motion in General and about Mechanisms of Machines Especially in 1854 was the first Russian textbook of Theory of Machines and Mechanisms (Fig. 14) [66].

Feodor Orlov(1843-1892) in his books used the two level of classification, the $1^{\text {st }}$ level is classification according to the connection of mechanisms links, and the $2^{\text {nd }}$ level is Willis classification on motion transformation [67]. Dmitry Zernov(1860 - 1922) wrote the textbook Applied Mechanics, Part 1 - Theory of Mechanisms and Part 2 - Theory of Machines. A brief historical treatise on theoretical mechanics was published by D. K. Bodylev (1892) [68].The works of Willis, Chebyshef, and Reuleaux constitute the essence of today's theory of machines and mechanisms.

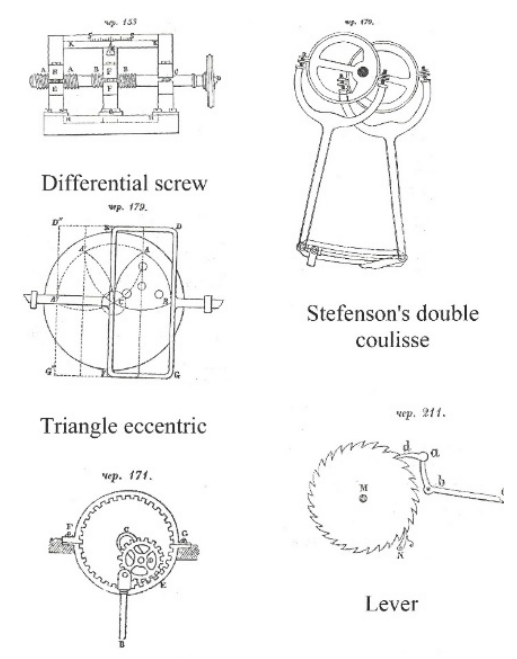

Figure 14. Examples of Moving Transmission [66].

The second half of 19th century can be considered as the Golden Age of the Theory of Machines and Mechanisms for the achieved theoretical and practicalresults that led to enhancements of machinery during the second Industrial Revolution.Various methods by which the different approaches and requirements of engineering design can be synthesized and evaluated appeared: mathematical analysis, computer modeling and simulation, experimental prototyping and testing, and extrapolating information from past experience [1-11].

During the whole $19^{\text {th }}$ century the traditional content of mechanics advanced in the field of applied mathematics. Euler's ideas for planar motion found extensive application in Smith's (1825-1916) Graphics (1889) where he makes extensive use of velocity and acceleration diagrams for mechanism analysis. Burmester's (1840-1927) Lehrbuch der Kinematic (1888) adopted most of Reuleaux methodology and also used geometric methods for mechanism displacement, velocity and acceleration analysis while Aronhold in Germany and Kennedy in England extended the use of instantaneous centers of velocity inventing the theorem of the three centers. Burmester's work addresses dimensional synthesis using geometric methods and was further extended by Pafnuti Tschebytschev (1821-1894) and S. Roberts (1827-1913) by the introduction of the triple generation of the coupler curves and had been formalized much later by Freudenstein and Sandor[1-11, 68-69].

Tschebytschev who had improved Watt's designtried to prove wrong the Peaucellier claim, that his mechanism was producing an exact straight line, by mathematical methods. Proving that a kinematic chain, no matter how complex, could not produce an exact straight line became an obsession to him for the rest of his life but he was unable to find the proof.Gruebler (1851-1935) developed criteria for the movability of a linkage, which can be considered as an important step towards number synthesis [69-70].

Oene Boetema (1901-1992) invented the method of instantaneous invariants in instantaneous kinematics providing a precision tool in mechanical engineering through kinematics [70-71]. K. Hain (1908-1995) was a pioneer of Applied Kinematics in Germany, he wrote 13 books and 380 scientific papers and designed 176 mechanism models. His kinematic heritage is preserved through the DMG-Lib research program in Germany [72].

Considerable contribution in mechanism design can be addressed to W. Lichtenheld (1901-1980) in Dresden [73-74]. U.A.Georgievich (1880-1936) [75], Xian_Zhou Liu (1890-1975) in China [76], and W. Wunderlich (1910-1998) [77]. F. Freudenstein (1926-2006) and his students produced important research results in every area of modern kinematics [76-80].

The nineteenth century, in the Hartenberg and Denavit words[7],

$\ldots$ is the end of the formative period, of an era in which many principles had been uncovered, analytical methods established, and the road to synthesis opened. Subsequent growth of these ideas, no longer nurtured only in Europe, has been of such scope that no short overview is possible... The full story of kinematics of mechanisms, doing justice to the many who practiced the art of mechanisms and contributed to the science of kinematics, is yet to be written...

\section{THE EVOLUTION OF MECHANISMS AND DESIGN METHODOLOGY}

Archimedes earned the honorary title "father of experimental science" because he not only discussed and explained many basic scientific principles, but he also tested them in a three-step process of trial and experimentation [9-11]. The first of these three steps is the idea that principles continue to work even with large changes in size. The second step proposes that mechanical power can be transferred from "toys" and laboratory work to practical applications. The third step states that a rational, step-by-step logic is involved in solving mechanical problems and designing equipment. His works contain a set of concrete principles upon which design can be developed as a science using mathematics and reason [1]. 
The aforementioned mechanical design principles can be traced to Filippo Brunelleschi, a Renaissance architect famed for designing the cupola for Santa Maria del Fiore in Florence in the 1420s. He introduced a method of design based on a six-step design process, identical in essence to the design principles of Archimedes, consisting of 1 . analyzing the design requirements, 2. making a concept design, 3. making a detailed design, 4. planning the manufacturing process, 5. manufacturing the parts and 6 . assembling the parts. Brunelleschi's six-step design process is considered the first systematic design process in engineering history and was carried out for 500 years [9-11].

About the seventeenth century, as societal development moved from the Mediterranean region to the Atlantic coast, the power is concentrated in the hands of centralized, monarchical governments. The concentration of capital leads to conditions of ample patronage of artists and craftsmen. Initially, the aim is the maintenance of a grandeur life in the royal court. Craftsmen are organized in guilds witch preserves their design secrets, but at the same time it confines it to mere empiricism.

By the second half of the eighteenth century, design has developed much beyond the royal court and with the French Revolution the royal manufactories enter the commercial competition and the high aesthetic quality is shared by machines and products for the general public.

The developments in machines and mechanisms in the 17th and 18th centuries are mainly driven by the need to support the development of the steam engine as the development of the mechanical clocks in the 15 th and 16th centuries.

Many of the advances in machinery in this era were made by an act of a genius inventor but many were conceived by the systematic reasoning of the engineer. Watt (1736-1819), in a letter to his son in November 1808, describes the methodology he utilized to design a linkage to trace an approximately straight path. Thus, he first considered the coupler points and the systematic synthesis of linkages with kinematic considerations.

As in many other areas, Euler (1707-1783), a nearly contemporary of Watt, has laid the foundations of kinematic analysis by considering a planar motion as superposition of a translation of a point and rotation about itand made a clear distinction of the kinematics and dynamics of a mechanism, the former being able to be studied without reference to the cause of the motion. An important addition to the Euler planar kinematics is the discovery by Johann Bernoulli of the instantaneous center of velocity in 1742 .

Since ancient times, most authors on machines dealt with whole machines or with their separate elements, such as Valturius (1472), Agricola (1550), Ramelli (1580), Branca (1629). Leupold(1724) seems to be the first to consider a mechanism, a machine consisting of different elements which are in some functional relationship with one-another separated from their work and referred to the modifications of motion. He describes machines which convert one type of motion to another, such as circular into rectilinear.

The automation in the production of the pulley blocks introduced by Marc Brunel (1769-1849), a French-born engineer, generated the need for a standardization of machine components. Christopher Pohlem (1661-1751), a Swedish engineer, introduced the "mechanical alphabet", a collection of different components labeled with alphabet letters. Every mechanism could be synthesized from elements of the mechanical alphabet just about as a poem consists of simple letters. One of Pohlem's students-assistants was Carl Cronstedt (1709-1779) who described in a sketchbook about one-third of the elements of Pohlem's mechanical alphabet. He concentrated on the movements which can be generated, in particular by the "mighty five" simple elements, while Archimedes and the Alexandrians dealt mainly with their force-amplifying features.

The first half of the 19th century, after the Napoleonic wars, there is a systematic attempt to apply engineering science to the design analysis of machines and it reached a mature level by this time, culminating to Poncelet's Introduction a la Mechanique Industrielle. Center for the efforts to apply engineering science to mechanical design was the Ecole Polytechnique, then a military school. The need for controlling the steam engine has generated a wealth of investigations in kinematics and the design of linkages. Synthesis of linkages can be viewed as a formal design method. However, it cannot be considered as a general mechanical design theory because it is limited to linkages by its nature.

In Germany, the von Humbolt model of universities developed strong ties with industry, in contrast to the Ecole Polytechnique which was mainly supported by the French government. Consequently, there is a rapid dissemination of engineering science in mechanical engineering. J. Weisbach wrote a book on Mechanics of Machinery and Engineering which had a high impact on design analysis. F. Redtenbacher was another German professor in the same period who combined his teaching with a designer's job at Escher and Wyss Manufacturing Co. In his books Principien der Mechanik und des Maschinenbaues (1852) and Konstruktion fuer den Maschinenbau (1862) includes not only mechanics and strength of materials considerations in the design analysis of machines, but introduces synthesis (konstruktion), a systematic methodology for finding design solutions and a set of general mechanical design principles:

a. Sufficient strength, b. Sufficient resistance to wear, c. Sufficiently low friction, d. Optimum use of materials, e. Easy manufacturing, f. Easy maintenance, g. Simplicity.

Redtenbacher's principles are contradicting and overlapping to a great extent, to become a formal system of design axioms. A more abstract set of design principles was developed by his student F. Reuleaux (1854) who addressed separately the function and the form considerations in the following two ground rules (Grundsaetze) of mechanical design:

a. (Function) The design must provide a uniform satisfaction of the design requirements. For example, in the case of loading by pressure, all parts should equally contribute to the support of the pressure.

b. (Form) The form of the design embodiment must have the highest possible symmetry.

The first principle can be regarded as an optimization principle. Equally loaded parts mean maximum 
utilization of the material, as Redtenbacher's principle (d). Stated in another form, when the design fails, it fails everywhere.

The second principle is essentially a minimum information principle. To an extent dependent on the particular design, it is not totally independent of the first principle, since symmetry results, in general, to lower manufacturing costs. It is not clear the extent to which Reuleaux is driven to this principle by mere aesthetic or optimum design considerations.

Reuleaux design principles lead to a balance between form and function considerations which were separated since the Alexandrian times and the decline of the ancient Greek philosophy and science.

Redtenbacher and Reuleaux have also developed to a final form the machine elements approach to the mechanical design methodology which dominated mechanical design up to our days. Reuleaux in fact, updated the five basic machine components of Heron to the following six: crank, wheel, cam, screw, ratchets, oneway rigidity elements (ie belts, chains, hydraulic lines).

In the nineteenth century, as the Industrial Revolution in England is fully developed, mechanization is generally adopted in production. This, does not always mean change in design methodology and production technology. The raising middle class demands that their newly acquired wealth and social status will show in a decorative effect, often excuberent and vulgar. While academics and intellectuals are debating on aesthetic matters in industrial production, industry itself is striving for novelty adopting stylistic views of past cultures.

This process results in severe violation of the natural and evolutionary process of the development of the form which, in many cases, is in sharp contrast to the product function.

The growing concern with the unbalance between utility and form is shown in an editorial of Cole's Journal of Design, in 1850:

"Design has a twofold relation, having in the first place a strict reference to utility in the thing designed; and secondarily, to beautifying or ornamenting that utility. The word design, however, with the many has become identified rather with its secondary than with its whole signification with ornament, as apart from and often as opposed to, utility. This was the reason for many of those great errors in taste which are observed in the works of many designers."

This view was further stressed by Colburn, a civil engineer, who in a 1871 book on locomotives, wrote "none who aspired to become engineer should encourage any play of imagination involving the forms or proportions of a mere mechanism..."

In 1964 Sandor proposed a seven steps strategy for machine design that is similar to that of Brunelleschi. The seven steps proposed by Sandor are: formulation of the problem, design concepts, synthesis, analyzable model, analysis-experiment-optimization, presentation. Similar sequential design procedures were in use until the 1970s, when the notion of engineers working on product design in teams manufacturing and mechanical engineers took hold, and by the 1980s many engineering firms adopted this concept, called concurrent engineering [1]). This switch to concurrent engineering has changed the way engineers do their work, and around that time the advent of computer aided design has revolutionized engineering design [1].

In the 20th century, there is a reconciliation of aesthetic and utilitarian particularism as the result of a design aesthetics theory which was pursued by Semper, a German architect in the latter part of the 19th century. By 1920, a "machine aesthetic" has been developed emphasizing rather abstract geometric forms in close relation with the philosophy of functionalism. This reconciliation of aesthetics and utility came naturally in the process of social and economic evolution[1].

\section{CONCLUSIONS}

The precise nature of the design process is infinitely varied and therefore difficult to summarize in a simple design formula, or a precise definition. Whatever the particular situation, machine design today is a process of creation, invention and definition, involving an eventual synthesis of contributory and often conflicting factors, capable of reproduction, with acceptable quality of products and with specified reliability. Machine design is an applied science relying heavily on mechanics because no machine can defy the laws of physics or the strength limits of the materials the machine is made of. Even if a new machine was conceived by invention systematic machine design is needed to transform the concept into a working system that users will appreciate [1].

Investigating the work of individual scientists, mathematicians and engineers during the early-modern and modern times of mechanics and mechanism design, in conjunction with engineering education and Institutions, provides the basis for separating divisions of mechanics that appear in the course of time.

Basic scientific principles discussed and explained by Archimedes in the $3^{\text {rd }}$ century $B C$ formed the instrument upon which engineering was established as a science distinct from crafts and unrelated empirical rules. The influence of ancient and Middle Ages mechanics in the emergence of mechanics in the $17^{\text {th }}$ century and subsequent development of discrete systems, and furthermore on continuum mechanics starting in the $19^{\text {th }}$ and the $20^{\text {th }}$ centuries is investigated here. The study of the mechanics of the ancient world and the Middle Ages, and particularly that of the East, still invokes new source material that has to be investigated.

Rapid development of mechanics as a science in the $17^{\text {th }}$ century is connected with the development of manufacture (16-17 $7^{\text {th }}$ centuries), the industrial revolution $\left(18-19^{\text {th }}\right.$ centuries), the appearance of railways and the construction of bridges $\left(19^{\text {th }}\right.$ century), the advent of aviation at the start of the $20^{\text {th }}$ century, modern rocketry in the middle of the $20^{\text {th }}$ century. The development of science in the past century has grown into a direct productive force. the development of applied mechanics and afterwardsof industrial mechanics was part of a complex social, economic and cultural process which combined thedynamics of the industrial and scientific revolution in the context of a large quantity of practical knowledge accumulated over the centuries.

The contribution of Leonardo Da Vinci, Galilei and Newton, the redefinition of classical physics and mechanics, the separation of the study of kinematics and the 
study of machinery in the $18^{\text {th }}$ century, the early mechanization and the progress during the Industrial Revolution, yielded the development of engineering design as a systematic process in modern era. The works of Willis, Chebyshev and Reuleaux constitute the essence of the theory of mechanisms and machines, greatly contributed and enhanced engineering design.

Unlike discoveries of new natural phenomena, innovations in scientific theory are not simply additions to the sum of what is already known. Almost always the acceptance of a new theory demands the rejection of an older one. In the realm of theory, innovation is thus necessarily destructive as well as constructive. Many of the approximate theories cherished some decades ago are reduced in their importance, if not becoming obsolete. The history of science, and mechanics, reveals that large amounts of qualitative work have usually been prerequisite to fruitful quantification in the physical sciences. During the last three decades, mechanics of machines require the power of control theory for optimized operation. A symbiosis of machine mechanics and control theory is evident, this yielding to rapid scientific and technologic development.The theory of the mechanical behavior of solids and fluids provides the basis for the development of deeper mathematics and more rigid adherence to mathematical rigor. [26].

Mechanics supported by mathematical foundation became the primary force for the development of the design of machines and mechanisms in a systematic way. The development of mechanics was closely associated with the development of mathematical methods. The appearance and refinement of mathematical methods themselves permitted the statement and solution of more complicated problems of mechanics.

As already mentioned the precise nature of the design process is infinitely varied relying heavily on engineering science, and a systematic process. In an ASME report of 1986 it is mentioned that sometimes multiple, even conflicting, requirements and constraints must be reconciled. There are various methods by which the different approaches and requirements can be synthesized and evaluated: mathematical analysis, computer modeling and simulation, experimental prototyping and testing, and by extrapolating information from past experience.

Design theory of machines and systems with a large degree of automation emerged in the last decades at the borderline of two sciences: mechanics of machines and control theory. Mechanics of machines is constantly developing based on the theory of mechanisms and machines, while control theory is advancing aided by the classical theory of control. Mechanics of machines and control theory are facing a high level of control with respect to the most diverse parameters, criteria and indices, while mechanisms synthesis is complicated with the presence of hydraulic, electric, variable mass, and other types of links, and the application of optimization techniques. Robotic manipulators have an increasing role in production, dynamics and vibration analysis becoming crucial, along with clearances, lubrication, elasticity, damping, acoustics and noise control, and diagnostics.
The implication of analysis being an integral part of design in engineering has been ameliorated based on the development of mathematics and mechanics. Design and building of machines have been aided by the theory of mechanisms. In the field of the theory of the structure and classification of mechanisms there have been established not only methods of structural analysis of mechanisms of arbitrary complexity but also methods of structural synthesis. Appreciable results have also been obtained in the dynamics of machines. Besides, the traditional methods of dynamic analysis and synthesis of machines, fundamentally new approaches to the dynamics of machines are in evidence. Forecasting the future in any science is not easy, particularly in the present age of such rapid development in science and technology.

The basic trend in the development of contemporary technology is now the automation of all types of production with the aim of easing the physical labour of the working man, increasing labour productivity, improving the quality of goods, and ensuring mass production of consumer goods. Problems of the sensitization of robots, development work on artificial intelligence, and the interaction between robot, environment, and man are closely connected with the development of computer technology and methods of mathematical modeling.

As the complexity of machines and mechanisms built today increases, engineers heavily rely on science to predict the behavior of not-yet-built designs. The predictive ability for the behavior of new designs is now indispensable in engineering. It is worthy to mention that many Engineering Departments have integrated the Machines and Mechanism theory in Machine Design courses. The development of the theory of mechanisms and machines requires the closest possible association of scientists and practical workers. Actual practice constantly confronts theory with new problems, and theory in turn finds in practical work a basis for its scientific research.

Engineering is sometimes defined as the application of science to the solution of a problem of society at a profit. The accrediting agency for U.S. engineering curricula, the Accreditation Board for Engineering and Technology (ABET), prepared the following more formal definition: "Engineering is the profession in which a knowledge of the mathematical and natural sciences gained by study, experience, and practice is applied with judgment to develop ways to utilize, economically, the materials and forces of nature for the benefit of mankind". Both of these definitions explain that engineering is based on mathematics and science but is focused on the solutions of specific problems. Also, the solutions, because they are needed or desired by society, must meet certain legal, environmental, and economic constraints. On the other hand, from the first theories of inverse dynamics in the $19^{\text {th }}$ century, starting with Bertrand's problem [82], during the last five decades the revolution of computing took place with the emergence of computers in the 60ies. Computation provided a third pillar to the to the classical two pillars of the scientific method, theory and experiment, a pillar overlappping the traditional two but expanding each in ways never dreamed of before. 
A considerable contribution to the study of the development of engineering and the science of machines is being made in different countries thanks to the International Federation for the Theory of Machines and Mechanisms (IFToMM), the Institute of the History of Natural Science and Technology of the USSR Academy of Sciences and its continuation, the ASME Design Engineering Division, and other National and International Organizations, and scientific authorities.

\section{REFERENCES}

[1] Dimarogonas, A.D. Machine Design A CAD Approach, John Wiley and Sons, New York, 2001.

[2] Dimarogonas, A.D., On the Axiomatic Foundation of Design. ASME Design Engineering Conferences, Albuquerque, NM, Design Theory and Methodology, DE-53, pp. 253-258, 1993.

[3] Dimarogonas A.D. Philosophical Issues in Engineering Design, Journal of Integrated Design and Process Science Vol. 1,pp. 54-75, 1997.

[4] Dimarogonas, A.D. History of Technology VolsI, II, Macedonian Publications, Athens, 2001.

[5] Dimarogonas, A.D., S.A. Paipetis and T.G. ChondrosAnalytical Methods in Rotor Dynamics Springer 2013.

[6] Dimarogonas A.D., Vibration for Engineers, Prentice-Hall, Second Ed., 1996.

[7] Hartenberg, R.S., and J. Denavit, Kinematic Synthesis of Linkages. New York: Mc Graw-Hill, 1964.

[8] Artobolevski I.I. Some Problems in Mechanics andMachine Control Advances in Theoretical andApplied Mechanics Editors: Ishlinsky A. and F.Chernousko, Mir Publishers, Moscow, 1981.

[9] Chondros T.G. Natural Philosophy and theDevelopment of Mechanics andEngineering from the 5th century B.C.to Middle-Ages FME Transactions, Vol. 45, pp. 603-619, 2017.

[10]Chondros T. G., The development of machine design as a science from Classical Times to Modern Era, In: International Symposium on History of Machines and Mechanisms (Eds. H. S. Yan and M. Ceccarelli), Springer pp. 59-68, 2009.

[11]Chondros T. G. The role of Mechanism and Machine Science and IFToMM in Greece, Ceccarelli M. (Editor)Technology Developments, the role of Mechanism and Machine Science and IFToMMU, Springer Science+Business Media, 2010.

[12] Mikhailov G. K. History of Mechanics:Present State and Problems Advances in Theoretical and Applied Mechanics Editors: Ishlinsky A. and F. Chernousko, Mir Publishers, Moscow, 1981.

[13] Vickers, B., Ed.Francis Bacon. New York, Oxford University Press, 1996.

[14] Gaukroger, S., Francis Bacon and the Transformation of Early-modern Philosophy. Cambridge, U.K.; New York: Cambridge University Press (2001).
[15]Zoubov V. Quelques aspects de la theorie des proportions esthetiques de L. B. Alberti', Bibliotheque d'Humanisme et Renaissance, xxii, 1960.

[16] The Oxford Dictionary of Philosophy. Copyright (C) 1994, 1996, 2005 by Oxford University Press.

[17] Vitruvius, M.P., $1^{\text {st }}$ Century AD. De Architectura (On Architecture) BOOKS I-V Loeb Classical Library, Translator Frank Granger, 1970.

[18] F. C. Moon, The Machines of Leonardo da Vinci and Franz Reuleux: Kinematics of Machines from the Renaisance to the XX Century (Ed. M. Ceccarelli), Book Series on History of Mechanism and Machine Science, 2,Springer, 2007.

[19]Zöllner F. and J. Nathan Leonardo da Vinci: The Complete Paintings and Drawings, Taschen Books GmbH, 2007.

[20]Reuleaux, E, Der Konstructeur. Braunschweig: J. Vieweg, 1872.

[21]Clagett, M., The Life and Works of Giovanni Fontana. Annali dell'Istituto e museo di storia della scienza di Firenze1, pp.5-28,1976.

[22] Munich, Bayerische Staatsbibiliothek, Cod. Icon. 242 Bellicorum Instrumentorum Liber.

[23]Zielinska T., Nicolaus Copernicus (1473-1543) History of Mechanism and Machine Science 1, Distinguished Figures in Mechanism and Machine Science, Their Contributions and Legacies, Part 1. Edited by Marco Ceccarelli, University of Cassino, Italy, Springer, The Netherlands, ISSBN 978-14020-6365-7, pp.117-134, 2007.

[24] Gies, Frances and Joseph, Cathedral, Forge, and Waterwheel: Technology and Invention in the Middle Ages Harper Perennial, New York,1994.

[25] Clark H, L. Hoover, H. Hoover,Georgius Agricola De Re Metallica Translated from the First Latin Edition of 1556 with Biographical Introduction, Annotations and Appendices upon the Development of Mining Methods, Metallurgical Processes, Geology, Mineralogy \& Mining Law from the earliest times to the 16th Century. Published for the Translators by The Mining Magazine Salisbury House, London E.C., 1912.

[26] Ceccarelli M. Early TMM in Le Mecaniche by Galileo Galilei in 1593 Mechanism and Machine Theory41, pp. 1401-1406, 2006.

[27] Engels, F., Anti-Dühring Foreign Langiuage Press, $1^{\text {st }}$ edition, 1976.

[28] Lenin V.I. Lenin Collected Works, Progress Publishers, Moscow, 14, pp. 17-362,1972.

[29] Aldrich, J., Karl Pearson (1857-1936), International Encyclopedia of the Social and Behavioral Sciences16, pp. 11159-11163, 2001.

[30] A W F Edwards, R A Fisher on Karl Pearson, Notes and Records Roy. Soc. London48 (1) pp. 97-106, 1994.

[31] Les origines de la statique, 2 vols., Paris: Hermann. English Translation Grant F. Leneaux, Victor N. Vagliente, and Guy H. Wagener, The Origins of Statics, Dordrecht: Kluwer, 1991. 
[32] Duhem, P., La nature du raisonnement mathématique, Revue de Philosophie, 12, pp. 531-543, 1996, English translation.

[33] Duhem, P., Le système du monde, histoire des doctrines cosmologiques de Platon à Copernic, 10 vols, Paris: Hermann, 1959.

[34]Duhem, P., La théorie physique son objet et sa structure, 2nd ed., Paris: Chevalier et Rivière. English Translation Phillip Wiener, The Aim and Structure of Physical Theory, Princeton: Princeton University Press, 1954.

[35] Needham, P., Resisting Chemical Atomism: Duhem's Argument, Philosophy of Science, 75, pp.921931, 2008.

[36] Dugas, R., Histoire de la Mecanique, Préface de Louis de Broglie, Neuchâtel, Éditions du Griffon, 1950.

[37]Dugas R., La Mecanique au 17e siècle, Paris: Dunod, 1954.

[38] Truesdell, C., Essays in the History in Mechanics, Springer-Verlag, 1968.

[39] Ignatieff, Y.A. and H. Willig, Clifford Truesdell: Eine wissenschaftliche Biographie des Dichters, Mathematikers und Naturphilosophen. Aachen: Shaker Verlag, 1999.

[40] Von Karman, Theodor. Aerodynamics, Selected Topics in the Light of Their Theoretical Development. New York: Cornell University Press, 1954.

[41]Kármán, von, T., Aerodynamics New York, McGraw-Hill, 1963.

[42]Kármán, von, T., and L. Edson, The Wind and Beyond: Theodore von Karman, Pioneer inAviation and Pathfinder in Space, Boston, Little, Brown, and Co, 1967.

[43]Hallion, R.P., The Literature of Aeronautics, Astronautics and Air Power, USAF, Office of Air Force History, Washington D.C., 1984.

[44] Timoshenko, S.P., History of Strength of Materials, Dover Publications, N.Y., 1983.

[45] Ishlinsky A. Problems in General and Applied Mechanics Advances in Theoretical and Applied Mechanics Editors: Ishlinsky A. and F. Chernousko, Mir Publishers, Moscow, 1981.

[46] Ceccarelli M., Preliminary Studies to Screw Theory in XVIIIth Century Proceedings of a Symposium Commemorating the Legacy, Works and Life pof Sir Robert Stawell Ball upon the $100^{\text {th }}$ Anniversary of A Treatise on the Theory of Screws, University of Cambridge, Trinity College,2000.

[47] Rouse BallW. W. A Short Account of the History of Mathematics 4th Edition,1908.

[48] Walter Fischer: Aus der Geschichte des sächsischen Berg- und Hüttenwesens, Hamburg, 1965.

[49] Euler L. Mechanica, sine, Motus scientia analytice exposita. St. Petersburg, Russia: Petropoli: Ex typographia Academiae Scientiarum, 1736.
[50] Ceccarelli M., Screw axis defined by Giulio Mozzi in 1763 Proceedings of the IXth IFToMMM World Congress on Theory of Mechanisms and Machines, Milan, 4, pp. 3187-3190, 1995.

[51] Ceccarelli M. Screw Axis defined by Giulio Mozzi in 1763 and Early Studies on Helicoidal Motion, Mechanism and Machine Theory 35,pp. 761-770, 2000.

[52] Rubio F.J., J.J.Cuadrado, Development of "Course of Machines" at the Ecole Polytechnique from its origin to middle of the XIXth century Proceeding of International Symposium on History of Machines and Mechanisms Edited by Marco Ceccarelli. Kluwer Academic Publishers, pp. 271-279, 2000.

[53] Cuadrado J.J. Agustin de Bètancourt Y Molina (1758-1824) History of Mechanism and Machine Science 1, Distinguished Figures in Mechanism and Machine Science, Their Contributions and Legacies, Part 1. Edited by Marco Ceccarelli, University of Cassino, Italy, Springer, The Netherlands. ISSBN 978-1-4020-6365-7,pp. 3160,2007.

[54] Garcia Diego J.A., Eduardo L. Ortiz, On a mechanical problem of Lanz History and Technology Special Issue: French Institutions from the Revolution to the Restoration, 5(2-4), pp. 301-313, 1988.

[55] Ceccarelli M., Evolution of TMM (Theory of Machines and Mechanisms) to MMS (Machine and Mechanism Science): An Illustration Survey. China Machinery Press Proceedings of the 11th World Congress in Mechanism and Machine Science August 18-21, Tianjin, China., edited by Tian Huang, 2003.

[56] G. Coriollis Mecanique des Corpes Solides etc. 2e ed. Paris, 1844.

[57] Théodore Olivier, Théorie géometrique des engrenages. Paris, 1842.

[58]Hirschhorn J. Kinematics and Dynamics of Plane Mechanisms Mc-Graw-Hill Book Company, New York, 1962.

[59] Ceccarelli M., Italian Kinematics Studies in XIXth Centuyry International Symposium on History of Machines and Mechanisms: Proceedings HMM 2000, Kluwer Academic Publishers, The Netherlands,pp. 196-206,2000.

[60] Ceccarelli M., Francesco Masi (1852-1944) History of Mechanism and Machine Science 1, Distinguished Figures in Mechanism and Machine Science, Their Contributions and Legacies, Part 2. Edited by Marco Ceccarelli, University of Cassino, Italy, Springer, The Netherlands, pp.141-162, 2010.

[61]Biography or Third division of "The English encyclopedia", Vol. 4 Conducted by Charles Knight, London (1867).

[62] A. N. Kolmogorov, Mathematics of the 19th Century: Geometry, Analytic Function Theory, Birkhäuser, 1996.

[63] C Reid, A Long Way from Euclid (Courier Dover Publications, 2004. 
[64] Willis R., Principle of Mechanism, London, (1841), 1870- 2nd Ed.

[65] Rooney, J., William Kingdon Clifford (1845-1879) History of Mechanism and Machine Science 1, Distinguished Figures in Mechanism and Machine Science, Their Contributions and Legacies, Part 1. 2007 Edited by Marco Ceccarelli, University of Cassino, Italy, Springer, The Netherlands, pp.79116, 2007.

[66] Golovin A. and D. Mkrtychyan, Alexander Yershof (1818-1867) History of Mechanism and Machine Science, Distinguished Figures in Mechanism and Machine Science, Their Contributions and Legacies, Part 1. Edited by Marco Ceccarelli, University of Cassino, Italy, Springer, The Netherlands, ISSBN 978-1-4020-6365-7, pp.135-149, 2007.

[67] Golovin A., V. Tarabarin and Z. Tarabarina Feodor Orlov (1843-1892) Marco Ceccarelli Editor Distinguished Figures in Mechanism and Machine Science, Their Contribution and Legacies Part 2 Springer, pp. 175-198, 2010.

[68] Ceccarelli, M., and Koetsier, T., Burmester and Allievi: A Theory and Its Application for Mechanism Design at the End of 19th Century, ASME J. Mech. Des., 130(7), 072301, 2008.

[69] Roth, B. History of Mechanism and Machine Science 1, Distinguished Figures in Mechanism and Machine Science, Their Contributions and Legacies, Part 1. Edited by Marco Ceccarelli, University of Cassino, Italy, Springer, The Netherlands, ISSBN 978-1-4020-6365-7. Ferdinand Freudenstein (1926-2006), pp. 151-181, 2007.

[70]T. Koetsier, Oene Boetema (1901-1992) History of Mechanism and Machine Science 1, Distinguished Figures in Mechanism and Machine Science, Their Contributions and Legacies, Part 1. Edited by Marco Ceccarelli, University of Cassino, Italy, Springer, The Netherlands, ISSBN 978-1-40206365-7,pp. 61-78, 2007.

[71] Bottema, O., B. Roth, Theoretical Kinematics, Dover Publications, New York,1990.

[72]Kerle, H., Kurt Hain (1908-1995). History of Mechanism and Machine Science 1, Distinguished Figures in Mechanism and Machine Science, Their Contributions and Legacies, Part 1. Edited by Marco Ceccarelli, University of Cassino, Italy, Springer, The Netherlands, ISSBN 978-1-40206365-7, pp.183-215, 2007.

[73] Erdman, A.G. (Editor), Modern Kinematics: Developments in the Last Forty Years, John Wiley \& Sons, 1993.

[74]Luck, K. Willibald Lichtenheld (1901-1980) History of Mechanism and Machine Science 1, Distinguished Figures in Mechanism and Machine Science, Their Contributions and Legacies, Part 1. Edited by Marco Ceccarelli, University of Cassino, Italy, Springer, The Netherlands, ISSBN 978-14020-6365-7,pp. 247-265, 2007.

[75] Jatsun S., Ufimtsev Anatoly Georgievich (18801936) History of Mechanism and Machine Science
1, Distinguished Figures in Mechanism and Machine Science, Their Contributions and Legacies, Part 1. Edited by Marco Ceccarelli, University of Cassino, Italy, Springer, The Netherlands, ISSBN 978-1-4020-6365-7, pp. 319336, 2007.

[76]Hong-Sen Yan, Hsin-Te Wang, Chun-Wei Chen and Kuo-Hung Hsiao, Xian_Zhou Liu (1890-1975) History of Mechanism and Machine Science 1, Distinguished Figures in Mechanism and Machine Science, Their Contributions and Legacies, Part 1. Edited by Marco Ceccarelli, University of Cassino, Italy, Springer, The Netherlands, ISSBN 978-14020-6365-7, pp. 267-278, 2007.

[77] M. Husty Walter Wunderlich (1910-1998) History of Mechanism and Machine Science 1, Distinguished Figures in Mechanism and Machine Science, Their Contributions and Legacies, Part 1. Edited by Marco Ceccarelli, University of Cassino, Italy, Springer, The Netherlands, ISSBN 978-14020-6365-7, pp. 371-392, 2007.

[78] Moon, F.C. The influence of Archimedes in the machine books from the Renaissance to the $19^{\text {th }}$ century. History of Mechanism and Machine Science 11, The Genius of Archimedes-23 Centuries of Influence on Mathematics, Science and Engineering, Proceedings of an International Conference held at Syracuse, Italy, June 8-10, 2010 Springer Science+Business Media B.V. 2010 S. Paipetis and M. Ceccarelli (Editors), pp. 397-409, 2010.

[79] Ceccarelli M. The Mechanics of Archimedes towards modern mechanism design. History of Mechanism and Machine Science 11, The Genius of Archimedes-23 Centuries of Influence on Mathematics, Science and Engineering, Proceedings of an International Conference held at Syracuse, Italy, June 8-10, Springer Science+Business Media B.V. 2010 S. Paipetis and M. Ceccarelli (Editors), pp. 177-187,2010.

[80]Roth, B. Ferdinand Freudenstein (1926-2006), Resonance, pp. 690-698, August 2010.

[81] Arthur G Erdman (Editor), Modern Kinematics: Developments in the Last Forty Years, John Wiley \& Sons, 1993.

[82] Galiulin, A.S. Inverse Problems of Dynamics, Mir Publishers, Moscow, 1984.

\section{РАЗВОЈ МЕХАНИКЕ И ИНЖЕЊЕРСКОГ ДИЗАЈНА И ТЕОРИЈЕ МАШИНЕ ОД ПЕРИОДА РЕНЕСАНСЕ}

\section{Т.Г. Хондрос}

Историја науке и механике суочава се са два узајамно повезана проблема: критичком акумулацијом и систематизацијом историјских информација о предмету истраживања и односом између догађаја и законитости њиховог развоја. У античко доба, почев од 5. века п.н.е. до почетка средњег века, 
природна филозофија је утицала на развој механике и инжењерства као науке, о чему је било речи у претходном ауторовом раду. Брз развој механике као науке отпочео је у 16. и 17. веку. Дизајн машина као примењене науке се у великој мери ослањао на механику. Од почетка 19. века механика је постајала теоријска основа све већег броја техничких дисци- плина које су биле у непосредној вези са развојем индустрије, разрадом технолошки нових процесних машина и индустријских објеката. У раду је приказана кратка историја развоја теорије машина и механизама, као и личности и академске институције које су извршиле утицај на теорију машина и механизама од средњег века до нама блиске прошлости. 